\title{
Cooperation among Local Governments in Realizing the National Strategis Area Development in Bangkalan Regency
}

\author{
Tamar Djaja $^{\mathrm{a}}$, Sumartono ${ }^{\mathrm{b}}$, Mardiyono $^{\mathrm{c}}$, Abdullah Said ${ }^{\mathrm{d}} *$ \\ ${ }^{a b c d}$ Brawijaya University, Malang, East Java, Indonesia
}

\section{ARTICLE INFORMATION}

\section{Article history:}

Data submission : 10 January 2018

$1^{\text {st }}$ revision: 10 March 2018

Accepted: 8 December 2018

Available online: 30 December 2018

Keywords inter-regional cooperation, National Strategis Area, development

\section{ABSTRACT}

The existence of National Strategis Area (NSA) in Bangkalan should not be ignored, but should be considered as a potential material that must be managed to create a progressive development for the people of Bangkalan Regency. Basically, the Bangkalan regency government can not carry out its own development, there must be a cooperation with the other that able to support the development optimization. Inter-regional cooperation for Bangkalan Regency has a very potential role, especially in the process of NSA development so that NSA will be able to become a trigger point in the development process. General question that should find the answer by researchers is "How is the implementation of interregional cooperation implemented by the Government of Bangkalan to develop the National Strategis Area?".

2018 FIA UB. All rights reserved.

\section{Introduction}

Development is a regional development effort to achieve the welfare of society. Regionally, there is a regional definition that has administrative boundaries that are formally determined through government regulations and functional areas adjusted according to socio-economic relations across administrative boundaries. Inter-regional cooperation can be an alternative of the concept of development with consideration as an effort to achieve efficiency, effectiveness, synergism and mutualism in areas agreed on cross-regional interests. The current policy relating to decentralization and regional autonomy has clearly provided the regulatory umbrella that encourages the implementation of inter-regional cooperation. Interregional cooperation is ultimately expected to be a solution that can transform potential conflicts of interregional interests into a mutually beneficial development process between regions.

Basically, Inter-Regional Cooperation begins with the awareness that the inter-regions need each other to achieve the common goal in the management of potential areas. Initiation of inter-regional cooperation can work effectively with the prefix of the similarity of issues faced by each region that requires a problemsolving model along with a commitment. Commitment to cooperate in handling issues is then agreed upon, and each region will prioritize common interests. These commitments need to be possessed by officials, both at the technical, managerial, and leadership levels so that the steps that are determined together will be implemented in the effective and efficient way.

The political aspect relates to the cooperation commitment is needed at the level of leadership, so that the political argumentation with the principle of "mutual benefit" becomes the basic philosophy of cooperation. Inter-Regional Cooperation benefits presented by Knip (in LAN, 2004) are as follows: a) Contribute to the local government strengthening, as inter-regional cooperation promotes democratic and sustainable development; b) Developing region have a real opportunity to exchange experiences with developed regions, and c) Contribute to community-based development opportunities.

Bangkalan Regency has a National Strategis Area which involves a large-scale space change in the management of national assets of a region. The National Strategis Area in Bangkalan Regency includes the footbridge of Madura side of Suramadu Bridge, the special port area of PT. Madura Industrial Seaport City in Socah SubRegency, as well as the international port of Tanjung Bulupandan in Klampis SubRegency. National Strategis Area which is entrusted by the central government to the Bangkalan Regency government becomes an important capital to create a prosperous

* Corresponding author. Tel.: +62-877-5111-1100; e-mail: djajatamar@gmail.com 
development in Bangkalan Regency. However, until 2017, the development of the National Strategis Area has not been optimal to be a trigger effect for economic, social and other aspects of Bangkalan regency. The advantages of the National Strategis Area can only be seen in several aspects, such as an increasing the land values and the ease of mobility of goods and services.

The central government established the Suramadu Area Development Agency (BPWS) through Presidential Regulation No. 27 of 2008 on the Suramadu Area Development Board to implement management, development and facilitate the acceleration of development in the region. However, with the slow development pattern even tends to be hampered, indicating the absence of synchronization between the authorized institutions in the acceleration of development, thus requiring a cooperation. Cooperation will be formed if there is awareness of mutual need among institutions to accelerate the development and economic growth of National Strategic Areas in Bangkalan regency. So that can be arranged an effective model of cooperation in realizing the development of National Strategic Areas in Bangkalan Regency involving several parties.

\section{Theory}

\subsection{Definition and The Essence of Inter-Regional Cooperation}

The changes of the government pattern from centralization to decentralization put forward on the basis of regional independence. To realize the regional independence based, it is need of support from resource optimization and development of collaboration among development actors. Regional cooperation will create mutually beneficial parties (winners and winners). Cooperation, in KBBI (Ministry of National Education (Departemen Pendidikan Nasional), 2014) is defined as an activity or effort was undertaken by several parties (institutions, government, etc.) to achieve common goals. Such definition cooperation is, at a glance, almost identical to the meaning of administration in a narrow perspective. This is also described by Flo Frank and Anne Smith (2000:5) which states that cooperation as a relationship of two or more parties who have a common goal, which promises to do something together. PKP2A I (2002) mentioned several considerations in strengthening the need for inter-regional cooperation, as follows: (a) The political reasons for creating a democratic government process; (b) Administrative reasons related to the limitation of government resources, so it is needed for the process of cooperation with other parties that can be done between institutions or between regions; and (c) Economic reasons with targets to reduce gaps, inequality, and to spur growth and productivity. In the end, inter-regional cooperation will improve the quality and continuity, and reduce the risk of a development process.

In this sense, the Municipal Cooperation Guide (LAN, 2004) mentions that the advantages of interregional cooperation include: a) Improving efficiency; b) Implementation of high-cost services or products; c) Minimization of activities duplication, and d) Effective and efficient problem-solving.

\subsection{Principles, Issus and Cooperation Form}

To be successful, cooperation should be able to apply the general principles that refer to "good governance" (Edralin, 1997), namely: a) Transparency; b) Accountability; c) Participatory; d) efficiency; e) Effectiveness; and f) Consensus. Adoption of good governance principles can be considered as an inescapable in the implementation of inter-regional cooperation.

The strategic issues related to the importance of inter-regional cooperation implementation are: a) Efforts to create Public Service Improvement; b) Border Area Development Efforts; c) Sustainable Spatial Management; d) Disaster Management and Conflict Potential Management; e) Poverty Alleviation and Regional Disparities Reduction; f) Increasing the role of higher levels of government; and g) Creating an Independent Regional Expansion.

PKP2A III LAN (2002) provides several models of inter-regional cooperation, as follows: a) Business Cooperation by Establishing a Permanent New Institution; b) Business Cooperation Without Establishing a New Body/ Institution; c) Service Cooperation by Establishing a Permanent New Institution; d) Service Cooperation Without Establishing New Institutions; and e) Technical Assistance Cooperation.

\subsection{Policy Framework for Inter-Regional Cooperation}

Within the policy framework, inter-regional cooperation has been regulated in Law no. 32/2004 on Regional Government, especially in articles 195-198, where the strategic dimensions of cooperation between regions include the institutional aspects and aspects of conflict resolution. In detail, the government has regulated the Inter-Regional Cooperation through Circular Letter of the Minister of Home Affairs Number 120/1730/SJ dated July 13, 2005. Reinforced by the issuance of Government Regulation no. 50 of 2007 on Procedures for the Implementation of Inter-Regional Cooperation.

\section{Research Method}

This research was conducted with a descriptive qualitative model that requires researchers to dig the information related to the research theme as much as possible. Inter-regional Cooperation in Realizing the National Strategic Area Development in Bangkalan Regency becomes an interesting theme because Bangkalan Regency has three national strategic areas which until now still has not given significant socioeconomic impact to the community.

The trend of development paradigm is now evolving into a form of interconnected development. The point is that the development should involve other actors. In this case, the government of Bangkalan Regency cannot use its own resources for the development process but must cooperate with other governments (central, provincial, or Regency). 


\section{Results and Discussion}

\subsection{Problems in the Cooperation Process of National Strategic Area Development of Bangkalan Regency}

Inter-regional cooperation in the development of the National Strategic Area shall be implemented by the Government of Bangkalan Regency. The implementation involves various parties which concerned to the development of the National Strategic Area in Bangkalan Regency. As an example, in the development of the Suramadu bridge area, the local government should have a good coordination with the central government representatives who are given the authority to manage the area. As another example, in the development of Tanjung Bulupandan Port and Madura Industrial Sea Port, the Government of Bangkalan Regency also needs to coordinate with the Surabaya City Government. That coordination is necessary because the existence of these two areas is to support the Port of Tanjung Perak in Surabaya. Problems arose related to this form of cooperation is the policy that has not been in line or overlapping. This condition leads to the poor commitment of the local government, especially in the provision of resources. This is contrary to the statement of LAN (2004), which mentioned that for the process of inter-governmental cooperation, the interested parties should first find the reasons for the encouragement of the implementation of the cooperation, so that the cooperation can be implemented in possible forms as needed.

\subsection{Actors Involved in the Process of Cooperation in the Development of National Strategic Area of Bangkalan Regency}

There are several actors involved in the process of national strategic area development in the Bangkalan Regency, namely:

a) Suramadu Area Development Board;

b) East Java Provincial Government;

c) Surabaya City Government;

d) Bangkalan Regency Government; and

e) Gerbangkertosusila Special Board.

The intergovernmental cooperation as mentioned above should be done well, beginning with the planning process. As previously discussed, the development of strategic national area created by the Government of Bangkalan Regency can be concluded, still not considering the pattern of development of its neighbouring regions. In fact, the existence of wellplanned cooperation will help the development process of the National Strategic Area. Ultimately, the development of the area can have a positive impact on the Bangkalan community and its partners. Generally, the resulting model emphasizes the periodic and binding coordination system through the MoU. In this case, Gerbangkertosusila Special Board acts as a coordinating facilitator. This is because Gerbangkertosusila Special Board is a party capable of accommodating all government level interests.

\subsection{Inter-Regional Cooperation Pattern of National Strategic Areas of Bangkalan Regency}

The effectiveness of provincial and district or municipality governments are still needs to be improved. This is because the result of the development could not meet the expectations. This refers to the authority of each actor in managing the National Strategic Area object. The National Strategic Area in Bangkalan Regency has not yet created an appropriate or positive effect, both socially or economically. Both local government or central government should be able to suppress their ego in holding an active collaboration for the sake of the National Strategic Area development of Bangkalan Regency. To be able to do so, the authority possessed by each actor can be implemented with the organization point of view, namely internal and external. Internally, it can be done through the improvement of quality management of planning and monitoring for cooperation activities; Increasing the intensity of monitoring and evaluation of the undertaken activities; Sharpening of shared vision and mission among institutions so that the programs priority which support the vision and mission could emerged; as well as the development of human resource capacity with various supporting and required skills. Externally, institutional effectiveness strengthening can be done by empowering the potential partners (especially private sector) in the management and development of National Strategic Area; Optimizing the non-governmental revenue such as NGOs to oversee the development process in National Strategic Area; Stimulate the community capacity to actively involved in the development process of National Strategic Area.

\section{Conclusion}

Inter-Regional Cooperation in the development process is an effort to build and improve the excellent service to the community. Actually, the cooperation which held by other regions has proven to improve the service performance in the certain development sector. It is also showed the positive correlation between the improving development sector with the satisfaction level as well as the community prosperity. Inter-Regional Cooperation could also effectively resolve the limitation problem of human resources and budget. Based on the analysis, it could be concluded that the impact of cooperation for the National Strategic Areas development in Bangkalan Regency as follows:

a) Inter-Regional Cooperation which holds by the government of Bangkalan Regency still not optimum. The main problem is the contradiction and overlapping of the regulations and policies. This resulted to the poor commitment in providing the resources;

b) Inter-Regional Cooperation is arranged to overcome the regulation and policy contradiction. Generally, the resulted model is emphasized on the periodical coordination system and bind through MoU. Gerbangkertosusila Special Board could act as a coordinating facilitator; and

c) The effectiveness of provincial and district or municipality governments are still needed to be improved. It could be done through two perspective, which is internally and externally. 
Internally, it could be done through the improvement of management quality of planning, monitoring, and evaluation, sharpening the shared vision and mission in line with the dynamics, and improvement of human resources capacity. Externally, it could be done by improving the institutional effectiveness and cooperation strengthening, empowering the private sector to optimize the non-governmental resources to increase the economic process and stimulate the community capacity.

\section{References}

Departemen Pendidikan Nasional. (2014). Kamus Besar Bahasa Indonesia (Pusat Bahasa), Edisi Keempat. Gramedia, Jakarta.

Edralin, J.S. (1997). The New Local Governance and Capacity Building: a Strategic Approach. Regional Development Studies, Vol. 3, pp.109150.

Frank, Flo., \& Anne Smith. (2000). The Partnership Handbook. Canada: Ministry of Public and Government Services.

LAN. (2004). Pengelolaan Penyelenggaraan Kerjasama Antar Daerah: Tinjauan Atas Beberapa Ketentuan dan Substansi dalam

Penyelenggaraan Kerjasama Antar Daerah. LAN, Jakarta.

PKP2A I LAN. (2002). Hubungan Kerjasama Pembangunan Antar Daerah(Laporan Hasil Penelitian). LAN, Bandung.

PKP2A III LAN. (2002). Hubungan Kerjasama Pembangunan Antar Daerah(Laporan Hasil Penelitian). LAN, Bandung. 